\title{
THE RE-ESTABLISHMENT OF IDEOLOGEME JUSTICE IN "GREY-ZONE" MORAL EMOTIONS OF A RAISING VICTORIAN IDEOLOGY
}

\author{
Iryna Pinich \\ Kyiv National Linguistic University, Kyiv, Ukraine \\ ipinich@ hotmail.com
}

\begin{abstract}
The study investigates into the impetus of grey-zone moral emotions underlying the sustenance of intragroup power relations in the times of ideological transitions of the late $18^{\text {th }}$ and early $19^{\text {th }}$ centuries refracted in the fiction discourse of the pre-Victorian era. The article is based on the assumption that the lingual representation of emotional experiences defines the emotional conceptual structure of the people and establishes social rules for emotion display patterns. A qualitative content analysis of the pre-Victorian novel corpus has substantiated the working hypothesis about the transitory mechanisms of ideological shifts facilitated by the dominant emotional repertoire across the social groups of the time. The paper claims the centrality of justice concerns in the ideological potency of the emotional experience of envy, jealousy, resentment, and ressentiment. An in-depth co-occurrence analysis of lingual representation of justice-seeking emotional reactions testifies to re-establishment of religious ideologeme JUSTICE displayed in a whole-scale procurement of resignation and inhibition compatible with placating vice-related experiences. The study argues that the restoration of the ideologeme under conditions of fixed social stratification is aimed at the exploitation of the emotional kindling of waning religious ideology for the accedence of a newly rising secular Victorian ideology. The analysis of the interconnectedness of lingual representation of grey-zone moral emotional reactions has underpinned the conjecture about their correlation to the system of religious ethics in determining an explicit display of strong feelings of injustice as outward enmity, impiety, and apostasy.
\end{abstract}

Keywords: ideology; ideologeme; linguoideologeme; grey-zone moral emotions; justice; pre-Victorian novel.

\section{Introduction}

The ideological potency of moral emotions has been long recognised in the sentimentalism theories of Hume (1896) and Smith (2002), the major exponents of the Scottish school of emotionalist philosophy in the $18^{\text {th }}$ century. A more recent sentimentalist theory of mind argues the centrality of emotion within the preeminent irrationality of mind (Slote, 2014) and underpins modern claims on the significance of emotions in constructing the worldviews of people. The assertion is put forward by psychologists (Hochschild, 1979), anthropologists and sociologists (Fassin, 2013; Kozlova \& Simonova 2016). The position of CDA (Critical Discourse Analysis) is aimed at questioning the relation of emotion to the moral judgment system exposed in triggering attitudinal opinion towards socially relevant phenomena or in experiencing a collective emotion as a means of attachment to a certain social group (Van Dijk, 1998, p.61-62; p.122-123) for the purpose of sustaining the balance of power, especially in times of developing or changing ideologies.

Our previous study on the transitory nature of ideologies (Pinich, 2018) has proved the rise of Victorian MORALITY ideology from the donor RELIGION ideology brought by the dominant emotional repertoire of positive other-praising moral emotions (sympathy, gratitude, elevation, pride) (Pinich 2018a), and negative self-conscious moral emotions (guilt, shame, and embarrassment) (Pinich 2018b). The object of this study is grey-zone moral emotions: envy, jealousy, resentment and ressentiment. The study makes an attempt at establishing the role of these ambiguous moral forms in ideology transitions by means of outlining how escaping the opposition good and evil adds to the rationalisation of confusion within the moral judgment system in the transitory period. The multi-modal evaluative concern of these moral emotions requires an indepth analysis of their function as guardians of justice and moral order in favouring the mechanisms of social cohesion of Victorians.

The gradual transition from religious moral virtues to secular virtues extended assumedly to the preVictorian era retaining the ideological centrality of JUSTICE in an integrative model of MORALITY. As a prominent ideologeme, JUSTICE served as a linkage in understanding the shift in retribution procedures: from God's discipline to legal punishment endorsed by the authorities of the times. The study seeks to explain the consistency between the implicitness of the reactive attitudes of envy, jealousy, resentment, and ressentiment in the fictional discourse of the time and the inculcation of Victorian ideology by means of rediscovering the emotional ignite of vice-related feelings.

The purpose of the article is to test an assumption on the correspondence between restoring the ideologeme JUSTICE for the accedence of Victorian ideology and the prescriptive appeasement of grey-zone moral emotions in their verbal representation in the pre-Victorian novel corpus. The objectives of the paper involve: 1) establishing the transit of the ideologeme JUSTICE from religious ideology within the rise of the

Pinich, I. (2019). The re-establishment of ideologeme justice in "grey-zone" moral emotions of a raising Victorian ideology. Advanced Education, 12, 236-243. DOI: 10.20535/2410-8286.148784 
normative concern in the period of ideology shifts; 2) tracing the mechanisms of vice-related emotional ignition in the sustenance of the fixed power distribution across the society.

\section{Methods}

In pursuing the purpose of the paper, 22 novels of the pre-Victorian era written between 1780-1836 were selected from the Corpus of Late Modern English Texts (CLMET 3.1) kindly offered by its authors (De Smet, Flach, Tyrkkö \& Diller, 2015). The free text mining software - KH Coder was implemented to the text versions of the corpus. Along with the quantitative data analysis, other text manipulation techniques of cooccurrence analysis and concordancing were employed to minimise preconceptions and validate the results of the study.

The paper argues the fluid nature of ideologies observed in the semantic proximity of their lexical representations (linguoideologemes). Subsequently, ideologies in wane serve donor ideologies for the rising ones ignited by the dominant emotional repertoires of the time. The study questions the function of greyzone emotions in secular ideology promulgation and tests the co-occurrence of their lexical representations to the linguoideologemes of concurrent ideologies of RELIGION, CRIME \& PUNISHMENT, and MORALITY \& PRECEPTS.

The choice of the listed ideologies is substantiated by their relevance to the Victorian era ideological transitions tested in our previous studies and their assumed actuality for the earlier and the following periods. The paper claims that ideologies are refracted in language by a system of their verbal representations: full, partial and acquired/contextual linguoideologemes. Full linguoideologemes directly refer to the ideology issues (ideologemes) which establish the core of the conceptual structure of ideology. Accordingly, full religious linguoideologeme represent a doctrinal statement of a denomination and religious practices (e.g. Christianity, Evangelicalism, Eucharist) while full CRIME \& PUNISHMENT linguoideologemes relate to criminal activity and authorised statutory criminal sanctions (e.g. culprit, delinquent, justice, magistrate). Full moral linguoideologemes represent the aspects of manners and etiquette as in civility, complaisance, compliment, courtesy etc. Partial linguoideologemes denote ideologically pertinent aspects of social ethics of ideologies, and acquired linguoideologemes stand for lingual units that inherit their ideological potency through the content of lingual representation of other non-dominant ideologies in the context.

Primarily, the analysis of dictionary definitions and the componential analysis were employed to establish the semantic structure differences and correspondences of the lingual representation of grey-zone emotional reactions in their relation to justice both in modern English online dictionaries and Webster's complete dictionary of the English language that dates back to 1886. At this stage, the choice of lexeme bitterness was made to test the representation of the emotional attitude of ressentiment in the fictional texts of the pre-Victorian era as the very notion was missing from the frequency lists of the novels for the reason that it was introduced only in the end of the $19^{\text {th }}$ century.

To further establish the consistency between the moral emotions and attitudes of envy, jealousy, resentment, and ressentiment and the resilience of RELIGION as donor ideology along with the rising secular ideology, the qualitative content analysis was implemented in the following stages:

1. Writing coding rules for moral emotions of envy and jealousy, and emotional attitudes of resentment and ressentiment. The coding rules involve the ideographic synonyms of envy, jealousy, resentment and bitterness, retrieved from the online thesaurus dictionary brought by Dictionary.com;

2. Implementing KH Coder word association tool to further establish the co-occurrences and filter the results to remove the hits other than nouns;

3. Filtering edges and setting the degree of co-occurrence based on the Jaccard similarity coefficient to establish the plausible linkage of lexical representation of grey-zone moral reactions;

4. Close analysing of word association results by implementing the tool of KWIC Concordancing, and filtering words by minimal differential frequency of 1 ;

5. Plotting co-occurrence information with the strongest Jaccard coefficients by selecting the Top Number option and generating network charts of 20-30 nodes for the convenience of graphical representation (see Figure 1);

6. Selecting the option Thicker lines for stronger edges to demonstrate stronger co-occurrences in the target file;

7. Configuring co-occurrence networks by highlighting the minimum spanning tree, based on Prim method, to feature the most significant edges;

8. Setting colour coding to a colour scheme based on "communities" (sub-graphs) that are used to represent clusters of the network that are more closely associated with each other through colour coding; 
9. In-depth analysing of machine-generated co-occurrence networks to test the hypothesis of an impetus of moral reactions of envy, jealousy, resentment and ressentiment for the social cohesion in the rise of anti-egalitarian Victorian ideology.

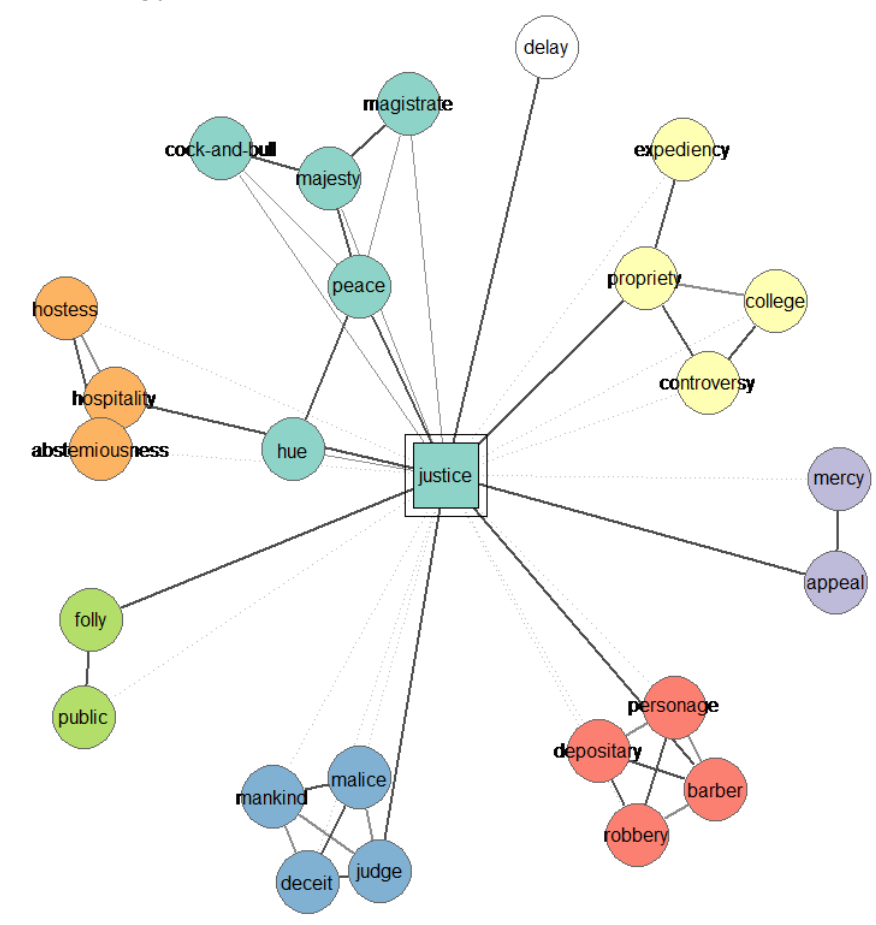

Figure 1. Co-occurrence network chart of linguoideologeme justice in Vivian Grey by Disraeli, 1826 (generated with the help of KH Coder)

\section{Results and Discussion}

The normative concern in the ideology transitions of the late 18 th and early $19^{\text {th }}$ centuries

The utilitarian ideology takeover which left religion far behind with its monastic approach to sins and the rightly penance in the afterworld (Cameron, 2002, pp.90-91) turned God's design into a matter of everyone's concern and judgment. The individual responsibility, repentance and redemption were being dissolved in the censure of mass morality (Grossman, 2006). The change, however, was a gradual process accompanied by several concurrent shifts in ideologies.

Intense public interest to crime and punishment in the $17^{\text {th }}$ and $18^{\text {th }}$ centuries (Ward, 2014, p.5) and the exposal in the print of atrocities of moral and social transgression highlighted a hallmark encroachment of secular ideology on religious ideology with the further attempt at redefinition of moral principles. Foregrounding CRIME \& PUNISHMENT as an expression of "ruling class ideology or an instrument of social control" (ibid., p. 10) aimed at raising public awareness of the acuteness of crime, fueled further concerns about crime rates, and consequently yielded the revision of the morality system. As a result, moral entrepreneurship opened space for numerous interpretations of the morality of an action. The ideological transition was favoured by the normative concern which was kindled by intensive sensations of discontent, dislike, displeasure, scorn, contempt, spite, anger, wretchedness, bitterness, and grief as displayed in the cooccurrences networks for the linguoideologeme justice.

Therefore, the ethical ideology transition was facilitated by the change in the interpretation of moral principles. The prominence and repute of moral principles above all (in total disregard of possible social or personal consequences) underwent significant transformations. Subsequently, the "principled ethical ideology" (Schlenker, 2008) of RELIGION gave way to an expedient secular ideology that recognised flexibility in attaining personal goals and was in strict conformity with the economic needs of the time.

Additionally, the accedence of secular ideology was aided by the rise of guilt-culture based on the underlying principle of individual moral responsibility in the face of law and public. The process was accompanied by the transition of religious virtue ideologemes to moral ideologemes of deontological ethics (Pinich, 2018). The guilt-inducing practices insured commonality and were linked both to CRIME \& PUNISHMENT and ECONOMY ideologies in sharing the ideologemes of DUTY and JUSTICE.

The call for justice, which was to be bestowed by the authorities of the state, dwelt on the whole-scale institutionalisation of law enforcements by the early $19^{\text {th }}$ century that characterised the English judicial 
system as close to total regulation (Conley, 1986, p.519). Retributive justice of utilitarianism was focused on keeping crime low and therefore people happy. The just deserts for the crime were retributions carried for the debt which the offender owed to the society in his lifetime, but not afterwards. Along with moral censure, the punishment meant being commensurate with the moral deficit of the criminal as represented in the cooccurrence charts of justice (do justice, justice of charge, and rely on the justice of judges). The gradual secularisation of justice is also observed in the semantic structure of the word as given in the dictionary entry of Webster's complete dictionary of the English language (Goodrich et al., 1886, p.732):

1. The quality of being just; the rendering to everyone his due, right, or desert; practical conformity to the laws and to principles of rectitude in the dealings of men with each other; honesty; integrity in commerce or mutual intercourse; strict conformity to right and obligation; rectitude; integrity; impartiality;

2. Conformity to truth and reality: equal distribution of right in expressing opinions; fair representation of facts respecting merit or demerit; impartiality;

3. Just treatment; requital of desert; merited reward or punishment;

4. Agreeableness to right; equity; justness; as, the justice of a claim;

5. [lat. justiciarius.] A person duly commissioned to hold courts, or to try and decide controversies and administer justice.

Dismantling the ideological structure of RELIGION involved the shift of JUSTICE from a religious ideologeme to an ideologeme of the secular ideology. The traces of the process can be observed in the expansion of the semantic domain of JUSTICE. The meaning of the word encompasses the synonyms of equity, with the specification of the possible conflict between justice and equity, and rectitude that has more reference to carrying out of law. The comprehensive notion of justice dwells on the principles of contemporary morality which recognised "absolute conformity to the rule of right" and differentiated among the three types of justice: "1) commulative, which gives every man his own property, including things pledged by promise; 2) distributive justice, which gives every man his exact deserts; 3) general justice, which carries completely out all the ends of law, though not in every case through the precise channels of commulative or distributive justice; as we see often done by a parent or a ruler in his dealings with those who are subject to his control" (ibid., p.733).

The co-occurrence analysis exhibited extensive edges of the linguoideologeme justice to the lexical items denoting relevance both to RELIGION (charity, clemency, gospel, kindness, mercy, repentance, and temple) and CRIME \& PUNISHMENT ideologies (authorities, judges, law, magistrate, officers of justice, proof, and trial). Therefore, the punishment for moral blameworthiness of the criminal putatively took its roots in religious practices, as the residue of God's general justice to His subjects can be traced in the ideologemes transition. The lingual representation of religious ideologemes interconnected with secular ideologemes through the meaning of lexeme justice is observed in the collocations: earthly power came nearest to God's, interposition of Providence, pray for mercy, and show mercy. The gradual loss of JUSTICE to the ideological structure of RELIGION is traceable in the concordances retrieved from the texts of fictional novels in CLMET 3.1:

When I have seen in my walks the irrational creatures of God, the birds and the beasts, governed by a kindly instinct in attendance on their young, often has it come into my head that love and charity, far more than reason or justice, formed the tie that holds the world, with all its jarring wants and woes, in social dependence and obligation together; and, in this year, a strong verification of the soundness of this notion was exemplified in the conduct of the poor haverel lassie Meg Gaffaw, whose naturality on the occasion of her mother 's death I have related at length in this chronicle (Annals of the Parish, Galt, J., 1821).

The instance of extreme secularisation of the ideologeme JUSTICE is represented in the fiction of the period by a collocation "to do justice to smth/smb" used in the meaning of treating adequately, fairly, or with full appreciation. The co-occurrences evince the explicit reference of justice to MORALITY \& PRECEPTS through the linkage to imprudence, morality, public chastisement, propriety, and smb's justice.

\section{The evaluative concern of grey-zone moral emotions in the rise of secular ideology}

The two-level structure of ideology arrangement (Homer-Dixon et al., 2013) involves the individual level of justice-related concerns on morality and fairness and the interpersonal level of claims to "distributive justice", "procedural justice", and "retributive justice" (Sabbagh \& Shmitt, 2016). Therefore, morality and justice-related cognitions and emotions have a prescriptive power for further moral behaviour and judgment both on the intrapersonal and in-group levels. Other-condemning emotions of righteous anger, contempt, and disgust are straightforward reactions of in-group judgments which are "apt to motivate morally corrective action" (Tangney, Stuewig, \& Mashek, 2007). These emotions seek a separate study on their input in ideology cultivation. The considerable issue of this paper lies in questioning the emotional zeal of grey-zone 
moral reactions of envy, jealousy, resentment, and ressentiment in facilitating the transition of ideologies in the late $18^{\text {th }}$ and early $19^{\text {th }}$ centuries.

The lack of unanimity in discerning the morality of grey-zone self-conscious emotions (see Ben-Ze'ev, 2002) attests to the ambivalence of their evaluative concern (see Table 1). The common feature retained by the emotions under analysis is the elicitor of the affects that lies in unjustified insults and undeserved inferiority of the victimised group. Meanwhile, the multi-modality of grey-zone emotions shares their core feature - claim to justice that anchors further commonality and egalitarianism. Subsequently, envy, jealousy, resentment and ressentiment are recognised as means of social cohesion (Kozlova \& Simonova, 2016, p.106), and modes of social alienation (ideological and historical) (Fassin, 2013), and are viewed in terms of desert and entitlement connected with concern for justice (La Caze, 2001).

Table 1. Multi-modal evaluative concern of grey-zone moral emotions

\begin{tabular}{|c|c|c|c|c|}
\hline & ENVY & JEALOUSY & RESENTMENT & RESSENTIMENT \\
\hline Inferiority concern & + & & & \\
\hline Deservingness concern & & + & & + \\
\hline Concern for justice & + & + & + & + \\
\hline Moral concern & & & + & + \\
\hline
\end{tabular}

\section{Envy and jealousy}

Contemporary invocation to moral value of negative sensations of envy and jealousy in Thomason (2015) and Protasi (2016) calls into question the unethical nature of the emotions and argue their permissibility in terms of justified emotional response to unfairness. The modern approach allocates envy and jealousy as guardians of justice and moral order along with resentment and righteous anger. The arguments in support of the relation of envy and jealousy to ideology proliferation are based on their motivation/action tendency at reframing and rationalising the moral implications of behaviour in the period of ideological shifts.

A close study of lingual representation of envy and jealousy in the concordances of the fictional texts in CLMET 3.1 testifies to the multimodality of their evaluative concern. Jealousy is interrelated with the deservingness concern and involves the perception of loss as is observed in the elicitors of the emotion: dishonor, falsehoods, thirst of fame, triumph of rival, trust imparted to a friend, cunning slander, and petty gossip. The concern for unjust distribution of goods and social positions (debts pressing, deprived of office, disrepute attached to poverty, fortune gone, mendicant on the public purse, notorious destitution, ridicule of embarrassments) is the most conspicuous in the co-occurrence networks of the linguoideologeme. Similarly to unfair encroachment on the experiencer's status, the undeserved inferiority is also displayed in the linkage to jealousy (fascination and brilliancy, intellect, and self-complacency).

The analysed networks of co-occurrences for envy display various representations of inferiority concern marked by maliciousness rather than benignity. The negative evaluation is elicited by either one's social status (ascendency of their comrade, fame and victory, less a triumph than an overthrow, potentate, restoration to dukedom, shadow of power, tyrant, vile triumph), economic position (huge profits, hardhearted forbearer, promotion), or one's personal traits (fine person, dignified manners, display of talents, love of all people). The feeling of undeserved inferiority though is devoid of emulation or aggression, but is of inert and spiteful nature (bitterness, bitter indignation, habitual gloom of temper, hardness of heart, malice, pang, regret).

The edges of the networks display a balanced role of envy and jealousy in the schemes of emotional behaviour of the time. Notably, a more profound look at the concordances evinces that motivation/action tendencies call both to the outward exposal of the emotions (curse blind and malicious power, prevent being ranked with the vilest men, hate politics, quench envy out of spite, insatiable thirst for vengeance, draw the attention of the crowd, say unkind words of jealousy and reproach) based on the intensity of the experience (fierceness, ferocity, hate, intensity, insincerity, jealousy burning in my bosom, pique of jealousy, wrath of jealousy), as well as to placating them (bitter power made him consent to drink to the dregs the bitter potion which envy had prepared for him; crouched under tyranny and kissed hands that were imbrued in my blood; forget wrath and vengeance and descend to prayer; jealousy mingled with compulsion; jealousy had faded back into the remoter depths of his mind; prevent jealousy, suppress jealousy, weep from vexation and envy). The ambiguity of "feeling rules governed by the social rules" (Hochschild, 1979) of the time that is 
represented in the fiction novels reveals the hedging function of envy and jealousy in the emotional management of the feeling of unjust and undeserved inferiority of their experiences.

Furthermore, the linguoideologemes envy and jealousy evince the extensive linkage to morality (envy + misconduct, uncivility; and jealousy + civility, politeness), social position (jealousy + gentry, lower orders, manufacturers), and jurisprudence (envy + punishment, and jealousy + deserts). Religion though occupies the central role in governing the display of emotions (envy + austerity, benevolence, candor, chastity, Christendom, clemency, forgiveness, Heaven, prayer, repentance, salvation; and jealousy + candor, cordiality, eulogium, perseverance, prudence, infidel, wrath). The resilience of the ideologemes ENVY and JEALOUSY within the frame of RELIGION is manifested in the assessment of the emotions that betrays their previous association with deadly sins: inconsolable regret, low sentiment, mortifying self-love, tortures, virgin agony, and woe.

The observed interrelatedness of envy and jealousy to the lexical units denoting various aspects of claims to justice testifies to the establishing of a strong tendency to internalisation of inhibition and malicious inertness in the evaluative concern of the victimised. Emotional cohesion was grounded on the ingroup recognition of immorality of envy and jealousy managed by the current social rules of emotional behaviour. Therefore, the attempts at rationalising the moral implication in the late $18^{\text {th }}$ and early $19^{\text {th }}$ centuries are strongly biased and underlie the anti-egalitarian views of Victorian ideology.

\section{Resentment and ressentiment}

The attitude to injustice serves the basic form for political subjectivation and can acquire different forms ranging from instantaneous ire, anger, and indignation to constantly suppressed feelings of undeservingness. Unlike explicitly manifested other-directed moral emotions, the long-term attitudes of resentment and ressentiment are directed at a repeated pattern of unjust actions at present or in the past. Therefore, resentment is delineated by Fassin (2013) from ressentiment as a means of ideological cohesion in the face of contemporary unjust political and economic treatment and triggers the feeling of anger and indignation. Whereas ressentiment is distinguished as a historical alienation of the victimised group experiencing rancour, bitterness, and acrimony, though potent of political subjectivation committed to equality.

Semantically, the distinction between the experiences of resentment and ressentiment can be based on the level of explicitness of demonstrating the attitude. Resentment, stemming from the feeling of being wronged, results in indignation or anger, whereas ressentiment is a state based on a defeatist and hostile attitude to the society and results from suppressed feelings of envy and hatred that cannot be satisfied. The notion ressentiment though came into use not earlier than the last quarter of the $19^{\text {th }}$ century when the notion was introduced by Nietzsche. To test the reification of ressentiment in the fiction of the late $18^{\text {th }}$ and early $19^{\text {th }}$ centuries the linguoideologeme bitterness was chosen as it appears to carry the closest meaning in transmitting the feelings of rancour, acrimony, and gall against the fixed order of things. As defined in the dictionary entry, bitterness is: "1) the state or quality of being bitter, either in a literal or figurative sense; an excessive degree of implacableness of passions or emotions; keenness of reproach or sarcasm; deep distress of mind; 2) a state of extreme impiety or enmity to God; 3) dangerous error, or schism, tending to draw persons to apostasy" (Goodrich et al., 1886, p.136).

Remarkably, in the fiction discourse of pre-Victorian novels, the representation of the linguoideologemes resentment and bitterness in the co-occurrences demonstrates a strong linkage to RELIGION ideology. Though, resentment co-occurrence networks evince a gradual transit to secular ideologies of CRIME \& PUNISHMENT (indictment, proof, trial), and MORALITY \& PRECEPTS (complaisance, uneasiness), meanwhile the evaluative concern of resentment is still viewed as sinful repining due to no great austerity of virtue and a shade in the character, darker passions which are so easily fermented and troublesome feelings which can affect even an extreme and rigid austerity of morals.

A noticeable avoidance in demonstrating indignation to social and/or economic unfairness is visible in the expressed elicitors of resentment, relating mainly to personal traits (coldness, cowardice, ill behaviour, puppyism) and individual rivalry (accuser, abuse, enemies, reproach, rival, small affronts). Intermittent reactions of angry compassion for their own disappointment and pity for the fate of somebody betray the lack of the potency of ideological cohesion in dissensus demonstration. Similarly, the "content of emotion experience" (Barret et al., 2007, p. 374) discloses the inertness of feeling (coldness, contempt, indifference, reserve, scorn, uneasiness). Furthermore, the paucity of action motivation (avoid every appearance of resentment and displeasure, can bear your resentment, cured passion, forebodings prevailed over resentment, refutation of monstrous charge, smother resentment) adds to the proliferation of temperance and coercion similar to ressentiment. 
The primary function of social cohesion throughout the period dwells on the historical alienation of ressentiment that received the incarnation of emotional sanctuary. In placating resentful feelings and cultivating inertness and inhibition, the evaluative concern of ressentiment is grounded on undeservingness and inferiority of the victimised group that is exteriorised in the feelings of regret, resignation, bitterness, grief, and humiliation. The claim to justice as observed in the linguoideologeme networks retains the moral guidance on distribution of the burdens of social cooperation (falsehood, hypocrisy, offence, prejudices, rebuke, reproach, rudeness, tyranny, world of much evil, world so perfidious and depraved) rather than individual material equality. Uneven distribution of benefits and burdens in utilitarianism doesn't offer egalitarian moral principles even if "the basic needs of one group are systematically satisfied by frustrating the basic needs of another" (Hayry, 2013, p.150). Therefore, the sacrifice for the sake of the welfare of the nation brings prudence as the key ideological stand of utility maximisation, deeply entrenching bitterness and helplessness of the victimised (anguish, disappointment, grief, regret, self-reproach, shame at weakness, sorrow, woe).

The divine nature of the rightness of action (as viewed by theological utilitarians of the late $18^{\text {th }}$ and early $19^{\text {th }}$ centuries) (ibid.) as well as fixed by deity the distribution of benefits and burdens, underlies the social cohesion of both within dominant and subordinated social groups. The emotional cohesion though differs in the polarity of feeling. The dominant group experiences their self-esteem enhancement whereas the victimised group in their alienation resorts to the "appeal to higher loyalty" - God in "search of relief and guidance" (Delaney, 2016, p.282). Subsequently, the bias to pietism of Victorians and their precursors testifies to the restoration of a redefined ideologeme FAITH, exploited as a verified means to maintain the power positions. The tendency is observable in the co-occurrences of the linguoideologeme bitterness which exhibit correlation with full religious linguoideologemes - ideology-based keywords (Christian, church, clergy, divine, doctrine, evil, heathen, Heaven, manse, martyr, monastery, prayer, prioress, repast, schism, soul, Supreme Being, vice, virtue) or partial linguoideologemes disclosing the major aspects of religious ethics (austerity, cordiality, humility, moderation, prudence, resignation), and contextual linguoideologemes that acquire ideological fervour in the context and serve the rhetorical figures in the ideological discourse (bent the head with resignation, bitterness of death, bitterness of vice, passionate tears, sorrowful heart, suffer with resignation).

The action/motivation tendency of bitterness calls for repentance (atonement, compliance, endurance, patience, tholing, suffering) as hardships are seen as a rightful retribution for the failings and shortcomings of humanity (ignorance, dissension, vice). Possible unacceptance of the plight of the victimised group is restricted by the fear of possible negative consequences of any protest activity (curse, death, grief, shame), and therefore failure to act subsequently triggers anxiety as a distinctive emotional domain of the $19^{\text {th }}$ century.

\section{Conclusions}

Sustaining the balance of powers in the late $18^{\text {th }}$ and early $19^{\text {th }}$ centuries is refracted in the contemporary fiction discourse which evinces numerical concurrent ideological shifts in the society. The ideologeme JUSTICE establishes the core value of the time exhibiting its resilience to the ideology of religion and serving along with that an ideological factor for bridging religious and secular ethics in a rising Victorian ideology. The ideological overlap in JUSTICE translates to its intermediary position in the transit from general and distributive justice to retributive justice.

The ideological transition triggers revisiting moral judgments and involves the implacability of greyzone moral reactions of envy, jealousy, resentment, and ressentiment in testing the justice of the social position of a group. A modern approach to the normative claim of these reactive attitudes argues their permissibility as a justified response to social unfairness and attests to their multi-modal concern for morality, justice, deservingness, and inferiority.

A study of lingual representation of the emotional responses in the network co-occurrences and in the concordances of fiction texts has demonstrated an overall tendency to the restoration of religious ideological fervour as a verified means of social power division. The justification of the fixed distribution of benefits and burdens of the society adds to the self-esteem enhancement of the dominant groups. Meanwhile, the subordinated groups undergo unification in the emotional alienation seeking the protection of God.

The edges of the networks of envy and jealousy display their hedging function in emotional management within the victimised group. The feelings of unjust and undeserved inferiority, envy and jealousy, are associated with deadly sins attributed to these affects. The emotions are devoid of any appeal to action or aggression, and the feeling rules suggest the emotive display of inert and spiteful nature. 
The internalisation of malicious inertness in short-lived feelings of envy and jealousy develops into a long-lasting attitude of ressentiment characterised by inhibition and defeatist feelings. Ressentiment performs the primary function of social cohesion and serves an emotional sanctuary for the victimised group. The promulgation of ressentiment patterns in the fiction of the pre-Victorian period, observed in the cooccurrences with full, partial, and acquired religious linguoideologemes, seeks to cultivate resignation and repentance by suppressing the strong feelings of injustice. The explicit display of dissent though is viewed as an indicator of outmost impiety and apostasy.

The lack of ideological salience of resentment in the fiction literature of the period is externalised in the expressed elicitors of the attitude and the inertness of feelings involved. A manifested avoidance in demonstrating indignation to social and/or economic unfairness betrays the procurement of coercion and condemns resentment as sinful repining.

\section{References:}

Barret, L., Mesquita, B., Ochsner, K. N., \& Gross, J. J. (2007). The Experience of Emotion. In Annual Review of Psychology, 58, 373-403. https://doi.org/10.1146/annurev.psych.58.110405.085709

Ben-Ze'ev, A. (2002). Are envy, anger, and resentment moral emotions? Philosophical Explorations, 5(2), $148-154$. https://doi:10.1080/10002002058538728

Cameron, S. (2002). The economics of sin: Rational choice or no choice at all? Chentelham, Northhampton: Edward Elgar Publishing.

Conley, C.A. (1986). Rape and justice in Victorian England. Victorian Studies, 29 (4), 519-536. Retrieved from https://liverpool.rl.talis.com/items/E3676FBD-E1F0-7773-1872-97F911428CDA.html

Delaney, T. (2016). Connecting sociology to our lives: An introduction to sociology. New York: Routledge.

De Smet, H., Flach, S., Tyrkkö, J. \& Diller, H.-J. (2015). The corpus of Late Modern English (CLMET), version 3.1: Improved tokenization and linguistic annotation. KU Leuven, FU Berlin, U Tampere, RU Bochum.

Fassin, D. (2013). On resentment and ressentiment: The politics and ethics of moral emotions. Current Anthropology, 54 (3), 249267. https://doi:10.1086/670390

Grossman, H. (2006). The beginnings of capitalism and the new mass morality. Journal of Classical Sociology, 6 (2), $201-213$.

https://doi.org/10.1177/1468795X06064861

Hayry, M. (2013). Liberal utilitarianism and applied ethics. London, New York: Routledge.

Hochschild, A. R. (1979). Emotion work, feeling rules, and social structure.In American Journal of Sociology, 85 (3), $551-575$.

Homer-Dixon, Th., Maynard, J.L., Mildenberger, M. et al. (2013). A complex systems approach to the study of ideology: Cognitiveaffective structures and the dynamics of belief systems. Journal of social and political psychology, 1 (1), 337-363 https://doi.org/10.5964/jspp.v1i1.36

Hume, D. (1978). A Treatise of Human Nature (L. A. Selby-Bigge \& P. H. Nidditch, Eds). Oxford: Claredon Press.

Kozlova, M.A. \& Simonova, O. A. (2016). Moralnye emotsii v ryadu mehanizmov sotsialnogo splocheniya [Moral emotions as the mechanisms of social cohesion]. Vestnik Pravoslavnogo Svyatotihonovskogo gumanitarnogo universiteta. Seriya 4: Pedagogika i psihologiya, 4 (43), 103-119.

La Caze, M. (2001). Envy and resentment. Philosophical Explorations, 4 (1), 31-45. https://doi.org/10.1080/13869790108523341

Pinich, I. (2018). Religious ideologemes in transition: A residue of theological virtues in the emotionalist ethics of Victorian novels. Lege artis. Language yesterday, today, tomorrow, III (1), 274-313. https://doi.org/10.2478/lart-2018-0008

Pinich, I. (2018a). Positive moral emotions in cultivating ideology of VICTORIAN MORALITY (a corpus-based study). Naukovi zapysky Nacional'nogo universytetu "Ostroz'ka akademiya", seriya "Filologiya", 1 (69), 2, 96-101. https://doi.org/10.25264/2519-2558-2018-1(69)/2-96-101

Pinich, I. (2018b). Negative self-conscious moral emotions in constructing Victorian moral identity (a corpus-based study). Pivdennyj arkhiv. Filologichni nauky: Zbirnyk naukovyh prac', 76, 78-85. Retrieved from http://www.pa.stateuniversity.ks.ua/archive/76_2018/16.pdf

Protasi, S. (2016). Varieties of envy. Philosophical Psychology, 29 (4), 535-549. https://doi.org/10.1080/09515089.2015.1115475

Sabbagh, C. \& Schmitt, M. (2016). Past, present, and future of social justice theory and research. In C. Sabbagh \& M. Schmitt (Eds), Handbook of Social Justice Theory and Research (pp. 1-11). New York: Springer. https://doi.org/10.1007/978-1-49393216-0_1

Schlenker, B. R. (2008). Integrity implications of principled and expedient ethical ideologies. Journal of Social and Clinical Psychology, 27 (10), 1078-1125. https://doi.org/10.1521/jscp.2008.27.10.1078

Slote, M. (2014). A sentimentalist theory of the mind. Oxford: Oxford University Press.

Smith A. (2002). The theory of moral sentiments (K. Haakonssen, Ed.). Cambridge: Cambridge University Press.

Tangney, J.P., Stuewig, J. \& Mashek, D.J. (2007). Moral emotions and moral behavior. Annual Review of Psychology, 58 (1), $345-$ 372. https://doi.org/10.1146/annurev.psych.56.091103.070145

Thomason, K. K. (2015). The moral value of envy. Southern Journal of Philosophy, 53 (1), 36-53. https://doi.org/10.1111/sjp.12095

Van Dijk, T.A. (1998). Ideology: A multidisciplinary approach. London: Sage Publications.

Ward, R. (2014). Print culture, crime and justice in 18th-century London. London: Bloomsbury academic.

Goodrich, Ch.A., Porter, N. \& Mahn, C.A.F. et al. (Eds.) (1886). Webster's Complete Dictionary of the English Language. London: George Bell \& Sons.

Webster, N. (1970). An American dictionary of the English language. New York: Johnson Reprint Corp.. 